Publisher homepage: www.universepg.com, ISSN: 2663-6913 (Online) \& 2663-6905 (Print)

https://doi.org/10.34104/ajpab.020.01670176

American Journal of Pure and Applied Biosciences

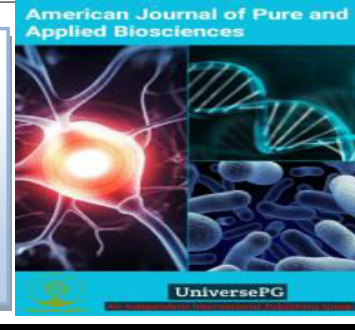

\title{
Decolorization and Degradation of Reactive Blue Dye Used in Jute and Textile Industries by a Newly Isolated Bacillus sp.
}

\section{Md. Zobaidul Hossen ${ }^{1} *$, Selina Akhter ${ }^{1}$, Tahmina ${ }^{1}$, Sharmin Akter ${ }^{2}$, Tahnin Bintay Kamal ${ }^{3}$, and Mahmuda Khatun $^{4}$}

${ }^{1}$ Dept. of Microbiology and Biochemistry, Bangladesh Jute Research Institute (BJRI), Dhaka, Bangladesh; ${ }^{2}$ Textile Physics Division, Bangladesh Jute Research Institute (BJRI), Dhaka, Bangladesh; ${ }^{3}$ Mechanical Processing Division, Bangladesh Jute Research Institute (BJRI), Dhaka, Bangladesh; and ${ }^{4}$ Product Development Division, Bangladesh Jute Research Institute (BJRI), Dhaka, Bangladesh.

*Correspondence: zobaidulgeb@gmail.com (Md. Zobaidul Hossen, Scientific Officer, Dept. of Microbiology and Biochemistry, BJRI, Dhaka, Bangladesh).

\begin{abstract}
For biodegradation of reactive dyes used in jute and textile industries, bacteria were isolated from a dyeing mill effluent. Bacteria having a remarkable ability to decolorize and degrade reactive dye were screened by using dye Reactive Dark Blue WR (RDB-WR). Cultural, morphological and biochemical characteristics were observed and based on these seven isolates having higher decolorizing capability was identified. Among these isolates, one of the prominent dye decolorizing isolates Bacillus sp. was taken for decolorization study. Under different physicochemical conditions, decolorization and degradation capabilities of Bacillus sp. were optimized by using RDB-WR, a dye commonly used in the jute and textile industries. This bacterium decolorized and grew well up to $500 \mathrm{mg} \mathrm{L}^{-1}$ of RDB-WR. Bacillus $s p$. showed significant decolorization approximately $86 \%$ at $200 \mathrm{mg} \mathrm{L}^{-1}$ of RDB-WR after $96 \mathrm{~h}$ of incubation. Optimum degradation of dye was achieved at $37{ }^{\circ} \mathrm{C}$. Maximum decolorization was observed at $\mathrm{pH} 7.0$ under static conditions. The study confirmed the potential of Bacillus in the biodegradation of Reactive Dark Blue WR. This bacterial isolate might be prospective in the biological treatment of dyeing mill effluents due to the high extent of decolorization.
\end{abstract}

Keywords: Bacterial isolate, Decolorization, Jute, Biodegradation, RDB, Textile industry, and Bacillus sp.

\section{INTRODUCTION:}

Environmental pollution is one of the major concerns of today's world. Due to rapid industrialization and urbanization large amount of wastes are generated and discharged into the environment and causing major pollution problem. Among many pollutants, effluents from dyeing industries are the major source of aquatic environmental pollution. Textile, pharmaceutical, cosmetic, jute, paper and food industries use synthetic dyes widely (Pandey et al., 2007; Kant, 2012). For complex aromatic molecular structures, synthetic dyes UniversePG I www.universepg.com are more recalcitant to biodegradation (Aksu, 2005; Dellamatrice et al., 2017). Textile and jute industries use around 10,000 different dyes, pigments and worldwide production is over $7 \times 10^{5}$ tons per annum (Aksu and Tezer, 2005; Daneshvar et al., 2007; Celia and Suruthi, 2016). There is a tremendous increase in dye utilization for rapid industrialization and man's demand for color (Mohan et al., 2002). Various color shades, easier application, high wet fastness, brilliant colors formation and consumption of minimal energy are the main reasons for extensive usage of reactive 
dyes in the textile and jute industries (Shah et al., 2013). Azo, anthraquinone and phthalocyanine are the common groups of reactive dyes (Axelsson et al., 2006) and these are mostly toxic, mutagenic and carcinogenic (Acuner and Dilek, 2004; Rauf and Ashraf, 2012; Stiborova et al., 2013). Aquatic environment can be damaged due to inappropriate discharge of reactive dye containing effluents. Aromatics, chlorides and metals of reactive dyes may be harmful for some aquatic life and photosynthesis in aquatic phototrophs may be affected severely for reduced penetration of light (Celia and Suruthi, 2016). For high tinctorial value less than $1 \mathrm{ppm}$ of the reactive dye is needed for color production (Gupta et al., 2003). Adsorption, coagulation-flocculation, oxidation and electrochemical are the physical and chemical methods normally used for removing dye from wastewater. But high-energy costs, by-products formation and production of high-sludge are the main limitations of these methods (Sarioglu et al., 2007; Celia and Suruthi, 2016). In contrast, bio-processing can surmount these drawback for being cost saving and environment friendly (Kurade et al., 2017).

Recent studies have focused on using microorganisms for degrading dyes from effluents (Chen et al., 2003; Acuner and Dilek, 2004; Mishra and Malik, 2014; Shen et al., 2015; Kurade et al., 2017; Veena et al., 2019). Bacteria, fungi, yeast and algae can decolorize and degrade wide range of dyes (Ayed et al., 2010; Kabra et al., 2011; Patel et al., 2013; Saratale et al., 2013; Veena et al., 2019) and many reactive dyes can be quickly degraded and even mineralized completely by bacteria under appropriate conditions (Chen et al., 2003; Asad et al., 2007; Jadhav et al., 2011; Kurade et al., 2012; Barapatre et al., 2017). In decolorization process, intermediate metabolites like aromatic amines are produced which can be degraded by the hydroxylase and oxygenase generated by bacteria (Pandey et al., 2007; Wanyonyi et al., 2017).

Jute is the golden fibre of Bangladesh. Jute and jute products have become second exporting goods of Bangladesh. Moreover, Bangladesh has emerged as one of the largest garment-manufacturing nations in the world. It has become the largest sector of Bangladesh in terms of foreign currency earnings and employment generation (Farhana et al., 2015,
Shuchismita and Ashraful, 2015). Huge amount of reactive dyes are used in manufacturing processes in textile and jute industries and are discharged through effluents with-out any treatment (Chindah et al., 2004). In Bangla-desh the physicochemical parameters of the dis-charged effluents are much higher than the standard value recommended by Department of Environment (Shuchismita and Ashraful, 2015). Reactive dyes present in surface and subsurface water make them aesthetically obnoxious. Human health hazards resul-ting in diseases, viz. dermatitis, mucous membrane, perforation of nasal septum and respiratory tract irritation, toxicological effects as well as allergy are caused by reactive dyes (Islam et al., 2011; Yadav, 2014; Rovira and Domingo, 2019).

Textile and jute effluents impart a chemical load to the environment and make the environment quite unacceptable. People living near dyeing industries are now being in danger for environmental polution (Sultana et al., 2009). Therefore, a sustainable bioprocess is very essential to remedy the toxicity caused by the reactive dyes present in the untreated industrial effluents. For this reason, finding reactive dyesdegrading bacterial isolates from the native environment is quite important. Bacteria present in the jute and textile effluents might have reactive dye degrading ability. A number of studies have revealed absorption and degradation of dyes by microorganisms (Mishra and Malik, 2014; Shen et al., 2015; Kurade et al., 2017; Veena et al., 2019), further studies are essential to develop biotechnology to detoxify and degrade the reactive dyes in effluents generated from jute and textile industries. In this study, bacteria were isolated and identified from dyeing mill effluent. Different physicochemical parameters were optimized for decolorization of Reactive Dark Blue WR (RDB$\mathrm{WR}$ ), one of the reactive dyes used in jute and textile industries.

\section{MATERIALS AND METHODS:}

2.1. Chemicals - A reactive dye-namely Reactive Dark Blue WR (RDB-WR), used in jute and textile industries was collected from a dyeing industry located at Chittagong, Bangladesh. All other chemicals were purchased from Sigma Aldrich, India unless noted. 
2.2. Sample collection and Estimation of total viable bacterial count - Samples were collected in sterile vials from effluent of dyeing industry located at Chittagong, Bangladesh. Transportation of samples was done immediately to the laboratory and stored at $4^{\circ} \mathrm{C}$ before used in the experimental purpose. Total viable bacterial count (TVBC) in these samples was enumerated as descrived by Azad et al. (2009). The unused samples were preserved in the same condition for repeatation of the experiment.

2.3. Isolation, screening and identification of dye decolorizing bacterial isolates - Samples collected from effluent were diluted up to $10^{4}$ times and cultured separately on the nutrient agar plate as described by Hossen et al. (2019). 14 bacterial colonies from nutrient agar plates were selected randomly for pure culture. Screening of these isolates for decolorization capability was carried out for 7 days using the reactive dye. For screening the bacterial isolates, having the dye degradation capability, one loop full of each bacterial isolate was inoculated in $10 \mathrm{ml}$ sterile nutrient (glucose, $1 \mathrm{gm} \mathrm{L}^{-1}$; beef extract, $1 \mathrm{gm} \mathrm{L}^{-1}$; peptone, $1 \mathrm{gm} \mathrm{L}^{-1}$ and yeast extract, $1 \mathrm{gm} \mathrm{L}^{-1}, \mathrm{pH} 7.0$ ) broth containing $200 \mathrm{mg} \mathrm{L}^{-1}$ of dye in the test tubes. Usually $100-300 \mathrm{mg} \mathrm{L}^{-1}$ dye is used for screening dye decolorizing bacteria (Lalnunhlimi and Krishnaswamy, 2016). Dye decolorizing isolates were selected and identified based on cultural, morphological and biochemical characteristics according to Bergey's Manual of Systematic Bacteriology (Staley et al., 2001).

\subsection{Measurement of decolorization extent - A $5 \%$} $(\mathrm{v} / \mathrm{v})$ freshly cultured bacterial inoculum was inoculated into dye containing sterile nutrient broth in $50 \mathrm{ml}$ conical flask. The experiment was carried out at $37^{\circ} \mathrm{C}$ under static condition for a period as noted. Culture (2 $\mathrm{ml}$ ) was collected every $24 \mathrm{~h}$ and centrifuged at 8000 rpm for $10 \mathrm{~min}$ to remove bacterial cells. Decolorization extent was determined by measuring the absorbance of the culture supernatant at $635 \mathrm{~nm}\left(\lambda_{\max }\right)$ using a UV-visible spectrophotometer (Shimadzu UV1800, Japan). Decolorization extent was calculated using the following equation:

$$
\text { Decolorization extent }(\%)=\frac{\mathrm{OD} 1-\mathrm{ODt}}{\mathrm{OD} 1} \times 100
$$

Where, OD1 refers to the initial absorbance before UniversePG I www.universepg.com
Decolorization; ODt refers to the absorbance after decolorization.

2.5. Effects of different physicochemical parameters on dye decolorization of RDB-WR - Optimization of different physicochemical parameters RDBWR dye were performed. From the bacteria, one isolate from the genus, Bacillus (isolate 12) (Uddin et al., 2017), which was prominent decolorizer during screening of RDB-WR was selected. Media containing 50, 100, 200, 500 and $1000 \mathrm{mgL}^{-1}$ dye were subjected to the decolorization process to study the effects of initial dye concentration. The experiment was conducted at $37{ }^{\circ} \mathrm{C}$ and $\mathrm{pH}$ 7.0. To estimate the optimum temper-ature, the study was done at 30,37 and $45{ }^{\circ} \mathrm{C}$. The initial $\mathrm{pH}$ of the media was 7.0. To study the effects of different $\mathrm{pH}$ on the decolorization, $\mathrm{pH}$ of the media were adjusted to 5.0 to 9.0. The experiment was carried out at $37^{\circ} \mathrm{C}$.

2.6. Statistical analysis - Student's $t$ test was used for statistical analysis. A $P$ value of $<0.05$ was considered as statistically significant. Data were presented as the means of repeated experiments $(n=5)$.

\section{RESULTS AND DISCUSSION:}

3.1. Estimation of Bacterial Load - Total viable bacterial count (TVBC) of receiving water provides valuable statistics in monitoring various types of pollutants. The heterotrophic bacteria were counted by the spread-plate technique by using nutrient agar. Total viable bacteria found in the effluent were $5 \times 10^{2} \mathrm{CFU}$ $\mathrm{ml}^{-1}$. TVBC of normal pond water $\left(2 \times 10^{6}\right)$ was also enumerated (Table 1). Data reported herein suggested that this effluent may be toxic to the growth and survival of normal microflora.

Table 1: Total viable bacterial count of different sources of sample.

\begin{tabular}{|l|c|}
\hline Sample & CFU/ml \\
\hline Dyeing mill effluent & $5 \times 10^{2}$ \\
\hline Pond water & $2 \times 10^{6}$ \\
\hline
\end{tabular}

3.2. Isolation, screening and identification of dye decolorizing bacterial isolates - For investigating the ability to decolorize RDB-WR, fourteen bacterial isolates were selected randomly from the nutrient agar 
plate. Screening for dye decolorization of these isolates was carried out in decolorizing nutrient broth for seven days by using the reactive dye $\left(200 \mathrm{mgl}^{-1}\right)$ (Table 2). Seven isolates that decolorized the dye were chosen for further study. Cultural, morphological and biochemical characteristics indicated that these seven isolates belonged to the bacterial genus of
Bacillus (2 isolates), Pseudomonas (2 isolates), Aeromonas (1 isolate), Alcaligenes (1 isolate) and Serattia (1 isolate). The morphological and biochemical characteristics of these isolates are summarized in Table 3. We selected isolate 12 (Bacillus $\mathrm{sp}$ ) that was prominent decolorizer of dye during screening for further study.

Table 2: Screening of dye degrading bacteria following incubation at $37^{\circ} \mathrm{C}$ for $170 \mathrm{~h}$.

\begin{tabular}{|c|c|c|c|c|c|c|c|c|c|c|c|c|c|c|c|}
\hline Dye & Observation period & 1 & 2 & 3 & 4 & 5 & 6 & 7 & 8 & 9 & 10 & 11 & 12 & 13 & 14 \\
\hline \multirow{7}{*}{$\begin{array}{l}\text { Reactive } \\
\text { DB WR }\end{array}$} & $24 \mathrm{~h}$ & - & - & - & - & - & - & - & - & - & - & - & + & - & - \\
\hline & $48 \mathrm{~h}$ & - & - & - & - & - & - & - & + & - & - & - & + & + & - \\
\hline & $72 \mathrm{~h}$ & - & - & - & - & - & - & - & + & - & - & - & + & + & + \\
\hline & $96 \mathrm{~h}$ & - & - & + & - & - & - & - & + & - & - & - & + & + & + \\
\hline & $120 \mathrm{~h}$ & - & - & + & - & - & - & - & + & + & - & + & + & + & + \\
\hline & $144 \mathrm{~h}$ & - & - & + & - & - & - & - & + & + & - & + & + & + & + \\
\hline & $170 \mathrm{~h}$ & - & - & + & - & - & - & - & + & + & - & + & + & + & + \\
\hline
\end{tabular}

Table 3: Morphological and biochemical characteristics of bacterial isolate.

\begin{tabular}{|l|l|}
\hline $\begin{array}{l}\text { Morphological and } \\
\text { biochemical tests }\end{array}$ & Bacterial isolate 12 \\
\hline Shape & Rod \\
\hline Motility & + \\
\hline Catalase production & + \\
\hline Oxidase production & + \\
\hline Gram staining & + \\
\hline Indole test & - \\
\hline $\begin{array}{l}\text { Methyl red test } \\
\text { Voges-Proskauer test }\end{array}$ & + \\
\hline Citrate utilization & - \\
\hline $\begin{array}{l}\text { Triple Sugar Iron Agar } \\
\text { test (Slant/Batt) }\end{array}$ & K/A \\
\hline Maltose fermentation & + \\
\hline Lactose fermentation & - \\
\hline Glucose fermentation & + \\
\hline Spore test & + \\
\hline Bacterial genus & Bacillus sp. \\
\hline
\end{tabular}

Here, K/A = Red/Yellow

3.3. Effects of initial dye concentration on the decolorization of RDB-WR - Dye decolorization and degradation depend on initial dye concentration as it has strong inhibitory effects (Khehra et al., 2005; Kalme et al., 2007). For this reason, decolorization activity of Bacillus sp. was studied using different RDB-WR concentrations ranging from 50 to $1000 \mathrm{mg} \mathrm{L}^{-1}$ (Fig 1). The study showed that the decolorization decreased with an increase in RDB-WR concentration.

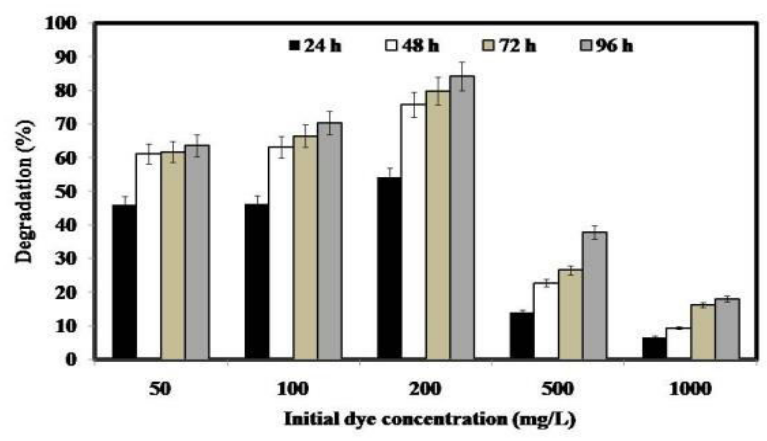

Fig 1: Effects of initial dye concentrations on decolorization of RDB-WR after $96 \mathrm{~h}$ of incubation with $5 \%$ inoculums. The initial $\mathrm{pH}$ in and the temperature were 7.0 and $37^{\circ} \mathrm{C}$, respectively.

It was observed that maximum decolorization by Bacillus sp. was approximately $85 \%$ with $200 \mathrm{mg} \mathrm{L}^{-1}$ RDB-WR (Ekhlas et al., 2014). Reports indicated the optimum decolorization by Bacillus species were (95$97 \%$ ) when $200 \mathrm{mg} \mathrm{L}^{-1}$ of azo direct blue 151 and azo 
direct red 31 were used (Lalnunhlimi and Krishnaswamy, 2016), Decolorization significantly decreased with $500 \mathrm{mg} \mathrm{L}^{-1}$ of RDB-WR and at $1000 \mathrm{mg} \mathrm{L}^{-1}$ of RDB-WR, decolorization was severely inhibited. Although bacterial growth was not notably decreased with $500 \mathrm{mg} \mathrm{L}^{-1}$ of RDB-WR, 30-40\% of the bacterial growth was inhibited by $1000 \mathrm{mg} \mathrm{L}^{-1}$ of RDB-WR in nutrient broth (data not shown).

\subsection{Effects of temperature on the decolorization of} RDB-WR - Variation in temperature decreases or increases the enzyme activity responsible for dye decolorization and degradation. Maximum decolorization by Bacillus sp. was obtained at $37^{\circ} \mathrm{C}$, although a significant decolorization occurred at $30{ }^{\circ} \mathrm{C}$ (Fig 2). The optimum decolorization temperature for RDB-WR by Bacillus was in conformity with Pseudomonas sp. decolorization of brilliant green, malachite green, fast green, congo red and methylene blue (Mali et al., 2000), A. faecalis PMS-1 decolorization of reactive orange 13 (Shah et al., 2012) and Bacillus subtilis decolorization of fast red (Mona and Yusef, 2008).

However, the decolorization was strongly inhibited at $45^{\circ} \mathrm{C}$, which might be due to the loss of cell viability or deactivation of the enzymes responsible for decolorization (Çetin and Dönmez, 2006). This result indicated that $30-37^{\circ} \mathrm{C}$ might be the best temperature for decolorization activity of this bacterial isolate.

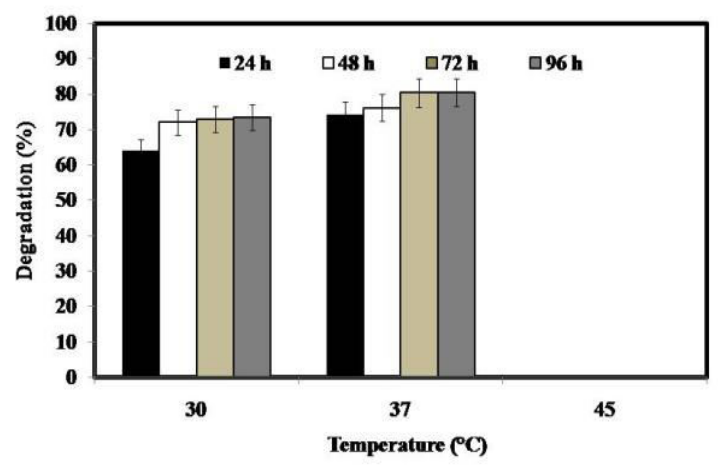

Fig 2: Effects of temperature on decolorization of RDB-WR after $96 \mathrm{~h}$ of incubation with 5\% inoculum.

The initial dye concentration and initial $\mathrm{pH}$ were adjusted to $200 \mathrm{mgL}^{-1}$ and 7.0, respectively.

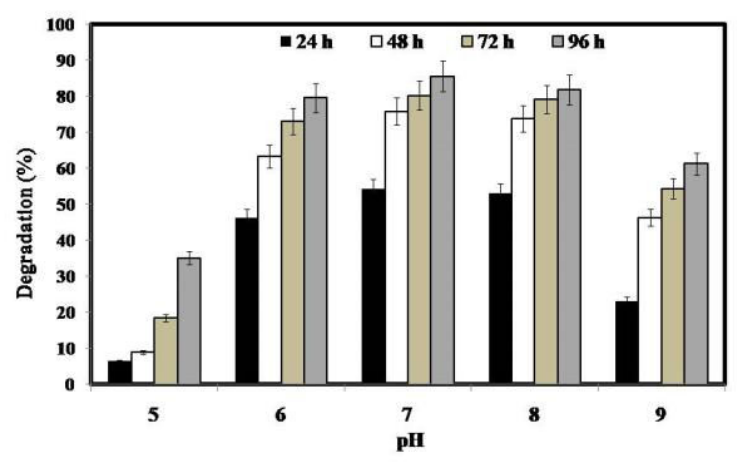

Fig 3: Effects of $\mathrm{pH}$ on decolorization of RDB-WR after $96 \mathrm{~h}$ of incubation with $5 \%$ inoculum. The initial dye concentration and the temperature were $200 \mathrm{mLL}^{-1}$ and $37^{\circ} \mathrm{C}$, respectively.

\subsection{Effects of $\mathbf{p H}$ on the decolorization of RDB-WR}

- The maximum level of decolorization of RDB-WR by Bacillus sp. was observed at $\mathrm{pH} 7.0$ (Fig 3). However, high level of decolorization (82\%) was also supported by $\mathrm{pH}$ 8.0. Moreover, significant levels of decolorization by this bacterial isolate were observed at $\mathrm{pH} 6.0$ - 9.0. This result indicated that this isolate could decolorize RDB-WR within a wide range of $\mathrm{pH}$, suggesting that this strain is potential organism for practical bio-treatment of dyeing mill effluents. The optimum $\mathrm{pH}$ for dye decolorization by A. faecalis PMS-1, Bacillus spp. and Enterobacter sp. is similar with the bacterial isolate used in the present study for RDB-WR decolorization (Shah et al., 2012; Lalnunhlimi and Krishnaswamy, 2016). The optimum $\mathrm{pH}$ for dye decolorization varies from acidic to alkaline condition (Saratale et al., 2011). Under alkaline condition reactive azo dyes bind to jute and cotton fibers by addition or substitution mechanisms so $\mathrm{pH}$ tolerance of decolorizing bacteria is very essential (Aksu and Donmez, 2003; Wang et al., 2013).

\section{CONCLUSION:}

Dye decolorizing bacteria were isolated from dyeing mill effluent in this experiment. 7 among these 14 bacterial isolates showed dye decolorizing ability. Physicochemical parameters for decolorizing RGBWR were optimized by Bacillus. Bacillus sp. showed decolorizing activity through a degradation mechanism and this could tolerate up to $1000 \mathrm{mg} \mathrm{L}^{-1}$ of RGB-WR. 
For high degradative and decolorizing ability against reactive dye used in the jute and textile industries, it can be anticipated that Bacillus sp. has a convenient application prospective in the transformation of dyeing mill effluents.

\section{ACKNOWLEDGEMENT:}

The authors would like to convey their heartiest thanks to all officers and lab assistants in BJRI for their continuous support and help to make this work a successful.

\section{CONFLICTS OF INTEREST:}

The author (s) declared no potential conflicts of the interest with respect to the research, authorship and/or publication of this article

\section{REFERENECES:}

1. Acuner E. and Dilek F. B. (2004). Treatment of tectilon yellow $2 \mathrm{G}$ by Chlorella vulgaris. Process Biochemistry, 39(5): 623-631. https://doi.org/10.1016/S0032-9592(03)00138-9

2. Aksu Z. (2005). Application of biosorption for the removal of organic pollutants: a review. Process Biochemistry, 40(3): 997-1026. https://doi.org/10.1016/j.procbio.2004.04.008

3. Aksu Z. and Donmez G. (2003). A comparative study on the biosorption characteristics of some yeasts for Remazol Blue reactive dye. Chemosphere, 50(8): 1075-1083. https://doi.org/10.1016/s0045-6535(02)00623-9

4. Aksu Z. and Tezer S. (2005). Biosorption of reactive dyes on the green alga Chlorella vulgaris. Process Biochemistry, 40(3):1347-1361. https://doi.org/10.1016/j.procbio.2004.06.007

5. Aravindhan R., Rao J. R and Nair B. U. (2007). Removal of basic yellow dye from aqueous solution by sorption on green alga Caulerpa scalpelliformis. Journal of Hazardous Materials, 142(1-2): 68-76. https://doi.org/10.1016/j.jhazmat.2006.07.058

6. Asad S., Amoozegar M. A., Pourbabaee A. A., Sarbolouki M. N. and Dastgheib S. M. (2007). Decolorization of textile azo dyes by newly isolated halophilic and halotolerant bacteria. Bioresource Technolology, 98(11): 2082-2088. https://doi.org/10.1016/j.biortech.2006.08.020

7. Axelsson J., Nilsson U., Terrazas E., Aliaga T. Alvarez and Welander U. (2006). Decolor- ization of the textile dyes Reactive Red 2 and Reactive Blue 4 using Bjerkandera sp. Strain BOL 13 in a continuous rotating biological contactor reactor. Enzyme and Microbial Technology, 39(1): 32-37. https://doi.org/10.1016/j.enzmictec.2005.09.006

8. Ayed L., Khelifi E., Jannet H. B., Miladi H., Cheref A., Achour S.and Bakhrouf A. (2010). Response surface methodology for decolorization of azo dye Methyl Orange by bacterial consortium: Produced enzymes and metabolites characterization. Chemical Engineering Journal, 165(1): 200-208.

9. Ayed L., Mahdhi A., Cheref A.and Bakhrouf A. (2011). Decolorization and degradation of azo dye Methyl Red by an isolated Sphingomonas paucimobilis: Biotoxicity and metabolites characterization. Desalination, 274(1): 272-277.

https://doi.org/10.1016/j.desal.2011.02.024

10. Azad A. K., Sawa Y., Ishikawa T.and Shibata H. (2009). Heterologous expression of tulip petal plasma membrane aquaporins in Pichia pastoris for water channel analysis. Applied Environmental Microbiology, 75(9): 27922797. https://doi.org/10.1128/aem.02335-08

11. Azad A. K., Ahmed J., Alum M. A., Hasan M. M., Ishikawa T. and Sawa Y. (2018). Prediction of arsenic and antimony transporter major intrinsic proteins from the genomes of crop plants. International Journal of Biological Macromolecules, 107(Pt B): 2630-2642. https://doi.org/10.1016/j.ijbiomac.2017.10.153

12. Azad A. K., Ahmed J., Alum M. A., Hasan M. M., Ishikawa T., Sawa Y. and Katsuhara M. (2016). Genome-Wide Characterization of Major Intrinsic Proteins in Four Grass Plants and Their Non-Aqua Transport Selectivity Profiles with Comparative Perspective. PLoS One, 11(6): e0157735.

https://doi.org/ 10.1371/journal.pone.0157735

13. Barapatre A., Aadil K. R.and Jha H. (2017). Biodegradation of Malachite Green by the Ligninolytic Fungus Aspergillus flavus. CLEANSoil, Air, Water, 45(4):1600045. https://doi.org/10.1002/clen.201600045 
14. Celia M. P. and Suruthi S. (2016 ). Textile dye degradation using bacterial strains isolated from textile mill effluent. International $J$. of Applied Research, 2(3): 337-341.

15. Çetin D. and Dönmez G. (2006). Decolorization of reactive dyes by mixed cultures isolated from textile effluent under anaerobic conditions. Enzyme and Microbial Technology, 38(7): 926-930.

https://doi.org/10.1016/j.enzmictec.2005.08.020

16. Chen C. H., Chang C. F., Ho C. H., Tsai T. L. and Liu S. M. (2008). Biodegradation of crystal violet by a Shewanella sp. NTOU1. Chemosphere, 72(11): 1712-1720.

https://doi.org/10.1016/j.chemosphere.2008.04.0 $\underline{69}$

17. Chen K.C., Wu J.Y., Liou D.J. and Hwang S.C. J. (2003). Decolorization of the textile dyes by newly isolated bacterial strains. $J$. of Biotechnology, 101(1): 57-68.

https://doi.org/10.1016/s0168-1656(02)00303-6

18. Chindah A. C., Braide S. and Sibeudu O. C. (2004). Distribution of hydrocarbons and heavy metals in sediment and a crustacean (shrimps - Penaeus notialis) from the Bonny/ New Calabar River Estuary, Niger Delta. African Journal of Environmental Assessment and Management, 9: 1-17.

19. Daneshvar N., Khataee A. R., Rasoulifard M. H. and Pourhassan M. (2007). Biodegradation of dye solution containing Malachite Green: optimization of effective parameters using Taguchi method. Journal of Hazardous Materials, 143(1-2): 214-219.

https://doi.org/10.1016/j.jhazmat.2006.09.016

20. Dellamatrice P. M., Silva-Stenico, M. E., Moraes L. A., Fiore M. F. and Monteiro R. T. (2017). Degradation of textile dyes by Cyanobacteria. Brazilian J. of Microbiology, 48(1): 25-31. https://doi.org/10.1016/j.bjm.2016.09.012

21. Ekhlas Uddin Md., Pulak Maitra, Hossain Md. Faruquee, Firoz Alam Md., (2014). Isolation and characterization of proteases enzyme from locally isolated Bacillus sp., American Journal of Life Sciences. 2(6), 338-344.

https://doi.org/10.11648/j.ajls.20140206.12
22. Farhana K., Syduzzaman M. and Munir M. S. (2015). Present Status of Workers in ReadyMade Garments Industries in Bangladesh. European Scientific Journal, 11(7). http://eujournal.org/index.php/esj/article/view/53 41

23. Gupta V. K., Ali I., Suhas and Mohan D. (2003). Equilibrium uptake and sorption dynamics for the removal of a basic dye (basic red) using low-cost adsorbents. Journal of Colloid and Interface Science, 265(2): 257-264. https://doi.org/10.1016/s0021-9797(03)00467-3

24. Hakim A., Bhuiyan F. R., Iqbal A., Emon T. H., Ahmed J. and Azad A. K. (2018). Production and partial characterization of dehairing alkaline protease from Bacillus subtilis AKAL7 and Exiguobacterium indicum AKAL11 by using organic municipal solid wastes. Heliyon, 4(6): e00646.

https://doi.org/10.1016/j.heliyon.2018.e00646

25. Hossen M. Z., Hussain M. E., Hakim A., Islam K., Uddin M. N. and Azad A. K. (2019). Biodegradation of reactive textile dye Novacron Super Black $G$ by free cells of newly isolated Alcaligenes faecalis AZ26 and Bacillus spp. obtained from textile effluents. Heliyon, 5(7): $1-11$.

https://doi.org/10.1016/j.heliyon.2019.e02068

26. Iqbal A., Hakim A., Hossain M. S., Rahman M. R., Islam K., Azim M. F., Ahmed J., Assaduzzaman M., Hoq M. M. and Azad A. K. (2018). Partial purification and characterization of serine protease produced through fermentation of organic municipal solid wastes by Serratia marcescens A3 and Pseudomonas putida A2. Journal of Genetic Engineering and Biotechnology, 16(1): 29-37.

https://doi.org/10.1016/j.jgeb.2017.10.011

27. Islam M. M., Mahmud K., Faruk O. and Billah M. B. (2011). Textile Dyeing Industries in Bangladesh for Sustainable Development. International J. of Environmental Science and Development, 2: 428-436.

28. Jadhav S. B., Phugare S. S., Patil P. S. and Jadhav J. P. (2011). Biochemical degradation pathway of textile dye Remazol red and subsequent toxicological evaluation by cytotoxi- 
city, genotoxicity and oxidative stress studies. International Biodeterioration \& Biodegradation, $\mathbf{6 5}(6)$ : 733-743.

https://doi.org/10.1016/j.ibiod.2011.04.003

29. Jadhav S. U., Jadhav M. U., Kagalkar A. N.and Govindwar S. P. (2008). Decolorization of Brilliant Blue $G$ dye mediated by degradation of the microbial consortium of Galactomyces geotrichum and Bacillus sp. Journal of the Chinese Institute of Chemical Engineers, 39(6): 563-570.

30. Kabra A., Khandare R., Kurade M.and Govindwar S. (2011). Phytoremediation of a sulphonated azo dye Green HE4B by Glandularia pulchella (Sweet) Tronc. (Moss Verbena). Environmental Science and Pollution Research, 18: 1360-1373. https://doi.org/10.1007/s11356-011-0491-7

31. Kalme S. D., Parshetti G. K., Jadhav S. U. and Govindwar S. P. (2007). Biodegradation of benzidine based dye Direct Blue- 6 by Pseudomonas desmolyticum NCIM 2112. Bioresource Technology, 98(7): 1405-1410. https://doi.org/10.1016/j.biortech.2006.05.023

32. Kalyani D. C., Patil P. S., Jadhav J. P. and Govindwar S. P. (2008). Biodegradation of reactive textile dye Red BLI by an isolated bacterium Pseudomonas sp. SUK1. Bioresource Technology, 99(11): 4635-4641. https://doi.org/10.1016/j.biortech.2007.06.058

33. Kant R. (2012). Textile dyeing industry an environmental hazard. Natural Science, 04(01). https://doi.org/10.4236/ns.2012.41004

34. Khadijah O., Lee K. K. and Faiz F. A. Mohd (2009). Isolation, screening and development of local bacterial consortia with azo dyes decolourising capability. Malaysian Journal of Microbiology, 51: 25-32.

35. Khehra M. S., Saini H. S., Sharma D. K., Chadha B. S. and Chimni S. S. (2005). Comparative studies on potential of consortium and constituent pure bacterial isolates to decolorize azo dyes. Water Research, 39(20): 5135-5141. https://doi.org/10.1016/j.watres.2005.09.033

36. Kumar K., Devi S. S., Krishnamurthi K., Dutta D. and Chakrabarti T. (2007). Decolorisation and detoxification of Direct Blue-15 by a bacterial consortium. Bioresource Technology, 98(16): 3168-3171.

https://doi.org/10.1016/j.biortech.2006.10.037

37. Kurade M. B., Waghmode T. R., Kagalkar A. N. and Govindwar S. P. (2012). Decolorization of textile industry effluent containing disperse dye Scarlet RR by a newly developed bacterial-yeast consortium BL-GG. Chemical Engineering Journal, 184: 33-41.

https://doi.org/10.1016/j.cej.2011.12.058

38. Kurade M. B., Waghmode T. R., Patil S. M., Jeon B. H.and Govindwar S. P. (2017). Monitoring the gradual biodegradation of dyes in a simulated textile effluent and development of a novel triple layered fixed bed reactor using a bacterium-yeast consortium. Chemical Engineering Journal, 307: 1026-1036.

https://doi.org/10.1016/j.cej.2016.09.028

39. Lalnunhlimi S. and Krishnaswamy V. (2016). Decolorization of azo dyes (Direct Blue 151 and Direct Red 31) by moderately alkaliphilic bacterial consortium. Brazilian Journal of Microbiology, 47(1): 39-46. https://doi.org/10.1016/j.bjm.2015.11.013

40. Mali P. L., Mahajan M. M., Patil D. P.and Kulkarni M. V. (2000). Biodecolourisation of members of triphenylmethane and azo group of dyes. Journal of Scientific and Industrial Research, 59: 221-224.

41. Mishra A. and Malik A. (2014). Novel fungal consortium for bioremediation of metals and dyes from mixed waste stream. Bioresource Technology, 171: 217-226.

https://doi.org/10.1016/j.biortech.2014.08.047

42. Mohan S. V., Rao N. C., Srinivas S., Prasad K. K. and Karthikeyan J. (2002). Treatment of simulated Reactive Yellow 22 (azo) dye effluents using Spirogyra species. Waste management, 22(6): 575-582. https://doi.org/10.1016/s0956-053x(02)00030-2

43. Mona E. M. and Yusef H. (2008). Decolorization of fast red by Bacillus subtilis HM. Journal of Applied Science and Research, 4(3): 262-269.

44. Pandey A., Singh P. and Iyengar L. (2007). Bacterial decolorization and degradation of 
azo dyes. International Biodeterioration \& Biodegradation, 59(2): 73-84.

https://doi.org/10.1016/j.ibiod.2006.08.006

45. Patel V. R., Bhatt N. S.and Bhatt H B̀. (2013). Involvement of ligninolytic enzymes of Myceliophthora vellerea HQ871747 in decolorization and complete mineralization of Reactive Blue 220. Chemical Engineering Journal, 233: 98-108.

46. Pearce C. I., Lloyd J. R.and Guthrie J. T. (2003). The removal of colour from textile wastewater using whole bacterial cells: a review. Dyes and Pigments, 58(3): 179-196. https://doi.org/10.1016/S0143-7208(03)00064-0

47. Rauf M. A. and Ashraf S. Salman (2012). Survey of recent trends in biochemically assisted degradation of dyes. Chemical Engineering Journal, 209: 520-530.

https://doi.org/10.1016/j.cej.2012.08.015

48. Rovira J. and Domingo J. L. (2019). Human health risks due to exposure to inorganic and organic chemicals from textiles: A review. Environmental Research, 168: 62-69. https://doi.org/10.1016/j.envres.2018.09.027

49. Saratale R. G., Gandhi S. S., Purankar M. V., Kurade M. B., Govindwar S. P., Oh S. E. and Saratale G. D. (2013). Decolorization and detoxification of sulfonated azo dye C.I. Remazol Red and textile effluent by isolated Lysinibacillus sp. RGS. Journal of Bioscience and Bioengineering, 115(6): 658-667. https://doi.org/10.1016/j.jbiosc.2012.12.009

50. Saratale R. G., Saratale G. D., Chang J. S. and Govindwar S. P. (2011). Bacterial decolorization and degradation of azo dyes: A review. Journal of the Taiwan Institute of Chemical Engineers, 42(1): 138-157.

https://doi.org/10.1016/j.jtice.2010.06.006

51. Sarioglu M., Bali U. and Bisgin T. (2007). The removal of C.I. Basic Red 46 in a mixed methanogenic anaerobic culture. Dyes and Pigments, 74(1): 223-229. https://doi.org/10.1016/j.dyepig.2006.02.001

52. Sen S. K., Patra P., Das C. R., Raut S. and Raut S. (2019). Pilot-scale evaluation of biodecolorization and biodegradation of reactive textile wastewater: An impact on its use in irrigation of wheat crop. Water Resources and Industry, 21: 100106.

https://doi.org/10.1016/j.wri.2019.100106

53. Shah M. P., Patel K. A., Nair S. S. and Darji A. M. (2013). Molecular characterization and optimization of Azo dye degrading Bacillus subtillis ETL-2013. OA Molecular and Cell Biology, 1(1): 2.

https://doi.org/10.13172/2054-7331--1-651

54. Shah P. D., Dave S. R. and Rao M. S. (2012). Enzymatic degradation of textile dye Reactive Orange 13 by newly isolated bacterial strain Alcaligenes faecalis PMS-1. International Biodeterioration \& Biodegradation, 69: 41-50. https://doi.org/10.1016/j.ibiod.2012.01.002

55. Shen N., Huo Y.C., Chen J.J., Zhang F., Zheng H. and Zeng R. J. (2015). Decolorization by Caldicellulosiruptor saccharolyticus with dissolved hydrogen under extreme thermophilic conditions. Chemical Engineering Journal, 262: 847-853.

https://doi.org/10.1016/j.cej.2014.10.053

56. Shuchismita D. and Ashraful I. (2015). A Review on Textile Wastewater Characterization in Bangladesh. Resources and Environment, 5: 15-44.

https://doi.org/10.5923/j.re.20150501.03

57. Staley J. R., Boone A. R., Brenner D. J., Vos P. D., Garrity G. M., Goodfellow M., Krieg N. R., Rainey F. A. and Schleifer K. H. (2001). Bergey's Manual ${ }^{\circledR}$ of Systematic Bacteriology. Springer $2^{\text {nd }}$ Edition.

58. Stiborova M., Dracinska H., Martinek V., and Frei E. (2013). Induced expression of cytochrome $\mathrm{P} 4501 \mathrm{~A}$ and $\mathrm{NAD}(\mathrm{P}) \mathrm{H}$ : quinone oxidoreductase determined at mRNA, protein, and enzyme activity levels in rats exposed to the carcinogenic azo dye 1-phenylazo-2-naphthol (Sudan I). Chemical Research in Toxicology, 26(2): 290-299.

59. Sultana M., Islam M. Shahidul, Saha R. and Mansur M. (2009). Impact of the Effluents of Textile Dyeing Industries on the Surface Water Quality inside D.N.D Embankment, Narayanganj. Bangladesh Journal of Scientific and Industrial Research, 44.

https://doi.org/10.3329/bjsir.v44i1.2715 
60. Tamura K., Peterson D., Peterson N., Stecher G., Nei M. and Kumar S. (2011). MEGA5: molecular evolutionary genetics analysis using maximum likelihood, evolutionary dis-tance, and maximum parsimony methods. Molecular Biology and Evolution, 28(10): 2731-2739. https://doi.org/10.1093/molbev/msr121

61. Thanavel M., Kadam S. K., Biradar S. P., Govindwar S. P., Jeon B.H. and Sadasivam S. K. (2018). Combined biological and advanced oxidation process for decolorization of textile dyes. SN Applied Sciences, 1(1): 97.

62. Uddin M. E., Ahmad T., Ray S. K., and Ahammed T. (2017). Thermotolerant extracellular proteases produced by Bacillus subtilis isolated from local soil that representing industrial applications. J. of Pure and Applied Microbiol. 11(2), 733-741. https://doi.org/10.22207/JPAM.11.2.12

63. Veena S., Rao B. and Venkata K. (2019). Biodegradation of Textile Azo Dyes. Nanoscience and Biotechnology for Environmental Applications. Cham, Springer International Publishing: 115-139.

https://www.springerprofessional.de/en/biodegra dation-of-textile-azo-dyes/16444740
64. Wang Z. W., Liang J. S. and Liang Y. (2013). Decolorization of Reactive Black 5 by a newly isolated bacterium Bacillus sp. YZU1. International Biodeterioration \& Biodegra-dation, 76: $41-48$. https://doi.org/10.1016/j.ibiod.2012.06.023

65. Wanyonyi W. C., Onyari J. M., Shiundu P. M. and Mulaa F. J. (2017). Biodegradation and Detoxification of Malachite Green Dye Using Novel Enzymes from Bacillus cereus Strain KM201428: Kinetic and Metabolite Analysis. Energy Procedia, 119: 38-51. https://doi.org/10.1016/j.egypro.2017.07.044

66. Yadav A. (2014). Toxic characterization of textile dyes and effluents in relation to human health hazards. J. of Sustainable Environmental Research, 3(1): 95-102.

67. Yu Z. and Wen X. (2005). Screening and identification of yeasts for decolorizing synthetic dyes in industrial wastewater. International Biodeterioration \& Biodegradation, 56(2): 109-114. https://doi.org/10.1016/j.ibiod.2005.05.006
Citation: Hossen MZ, Akhter S, Tahmina, Akter S, Kamal TB, and Khatun M. (2020). Decolorization and degradation of reactive blue dye used in jute and textile industries by a newly isolated Bacillus sp. Am. J. Pure Appl. Sci., 2(5), 167-176. https://doi.org/10.34104/ajpab.020.01670176 @) 